\title{
Difficult Collective Deliberations: Anthropological Notes Toward a Theory of Education
}

\author{
Hervé Varenne \\ Teachers College, Columbia University
}

Background/Context: In the 1970s, Lawrence Cremin urged researchers to remember that education is more than schooling. Few heeded this call, perhaps because of the absence of the theoretical framework needed to make this more than a platitude. As a cultural anthropologist, I argue that education is a fundamental human activity that is infinitely more complex than anything that can happen during learning lessons in school. The argument is a theoretical one bolstered by the case studies included in this special issue.

Policy Context: There are two main strains of research by those concerned with education as something that does not happen solely or even mainly in schools. In anthropology, it has been necessary to be aware of this given the absence of institutions easily recognizable as schools in many of the societies in which anthropologists have worked. But even in this discipline, the emphasis was more on incidental enculturation than on education as deliberate effort. In sociology and related fields, many have looked at nonschool environments as causal to the socialization that appears to be a precondition to success in schools. The point of reference remained schooling. Purpose: In this analytic article, I pick up two key terms in Cremin's definition: "effort" and "deliberation." Through a contrast with Bourdieu's theory of habitus, I show that both words make sense in terms of an amended take on Garfinkel's ethnomethodology, Lave's understanding of learning as movement through differentiated social fields ("communities of practice"), de Certeau's insistence on "enunciation," and Rancière's focus on productive ignorance. I show how all the case studies included in the special issue take us out of the world of early learning and into the world of continued efforts to change both oneself and one's consociates through often difficult collective deliberations.

Conclusions/Recommendations: Focusing on ubiquitous education about life conditions rather than early socialization or school-based skills reopens the question of the processes that actually

Teachers College Record Volume 109, Number 7, July 2007, pp. 1559-1588

Copyright $\odot$ by Teachers College, Columbia University

0161-4681 
constitute the school politically. If religion, ideology, artistic tastes, technologies, and so on, must be seen as developing essentially in and around institutions uneasily controlled by the "public," then the conversations by school people about schooling (its policies, prerequisites, and consequences) miss what remains most powerful in human life-the continued efforts by all to transform their conditions.

I have conceived of education in this essay as the deliberate, systematic, and sustained effort to transmit, evoke, or acquire knowledge, attitudes, values, skills, or sensibilities, and any learning that results from the effort, direct or indirect, intended or unintended. This definition obviously projects inquiry beyond the schools and colleges to a host of individuals and institutions that educate-parents, peers, siblings, and friends, as well as families, churches, synagogues, libraries, museums, settlement houses, and factories. And it clearly focuses attention on the relationships among the several educative institutions and on the effects of one institution's efforts on those of another. What is needed most for a sound historical understanding of these relationships—or linkages, as I have called them here-is a variety of investigations that study them in their own right, with explicit educational questions uppermost in mind (Cremin 1978, 567).

Let us pay attention to what, as educators, social scientists, and parents, we want to celebrate and understand. Here is humanity at work (from a personal observation):

A four-year-old girl, in a pew at church, is playing while her mother sings in the choir. She picks up the music program, looks intently at the front illustration (a wood print of the Resurrection of Jesus from the 16th century with the figures of two sleeping guards at the bottom). The child leans toward a 16-18 year-old-boy next to her, points at the guards and asks a question. The boy leans into her, answers, and then elaborates as he points to other parts of the picture. The child asks a new question that leads to further elaborations. And then she looks around and moves on to something else as the boy returns to what he had been doing.

Those of us directly involved in the project I am introducing hereanthropologists working around the world, in a multitude of settings, and from various perspective-take most seriously this human work of 
seeking knowledge, providing knowledge, framing knowledge, and then moving on. This is obviously something that individuals do, and they learn much in the process. But it is also social work, strongly framed and powerfully constrained, and yet open to alternate, possibly unauthorized, activities. It is work that is never done because it continually produces, along with learning, new forms of ignorance. And it is deliberate and deliberative work by all involved. Our sense is that considering all this as education is most likely to preserve the complexity of the work.

Specifically, we reopen the question of the definition of education that concerned the historian Lawrence Cremin when, in the 1960s and 1970s, he asked, What should be included in a history of American "education"? Many who preceded him, and many who came after him, settled the question easily. The history (and also sociology or anthropology) of education is to be the history of schooling and what can be shown to influence it. Cremin refused this answer. We join him in this refusal, and go further. He showed that education is something that happens "in many institutions." We argue that education is essential to the development of these institutions, their integration, and their change. Education is fundamental to sociability and is ubiquitous in the everyday life of all human beings.

We use the word "education" deliberately. "Learning," the word most often used in these contexts, is too narrow, as well as easily misleading. It is the case that all developments in learning theory, from Vygostsky to Lave, have established that individuals do not learn by themselves. They learn with others, and the social worlds they build make all the difference for what all will be known to have been known. "Learning," thus, is always a political process, and there cannot be any learning without some form of teaching. At any time, within any population, the social organization of learning can become dangerous, and liberating, to those who must participate. All work on resistance also suggests that, as educators have always known, individuals never fully accept what they are taught. These generalizations are well established in much developmental psychology, as well as the social sciences, when they address issues of consciousness, understanding, habits, and so on-and the parallel issues of false consciousness, misunderstanding, and prejudice. They are at the core of all theories of culture, as well as theories of hegemony. But the very breadth of these issues suggests the need for a word other than "learning." The alternate must move attention away from the storing of information by individuals to the collective activities productive of new information for all. And it must move attention to the public nature of the discussions about learning, teaching, and their organization-discussions that eventually change this organization. We propose the word "education" to the 
very extent that it is used to refer to a deliberate and deliberative human activity.

The word "education" may lead to a new form of confusion, for it has been made into a synonym for "schooling" as an institutional activity controlled by the modern State. ${ }^{1}$ This conflation is dangerous if it obscures the broader processes that constitute the School at any particular time. ${ }^{2}$ Consider, for example, some of the many matters that schools do not teach: almost everything having to do with the most significant religious tradition in a person's background; with popular or ethnic cultures; and with the most vital artistic forms or new technologies. ${ }^{3}$ The list keeps changing because of the very controversies about what must be taught in the school, about what may be taught, and about what must not be taught. All these matters become visible in conversations about the School, held outside the School, and in terms of forms of knowledge not fully controlled by the School. Where do people learn about the relationship between testing and knowledge? About creationism and intelligent design? About school vouchers? Bourgois (1996) has argued for the need to take seriously what all research in the metropolitan centers of postmodernity has shown: The streets are always more powerful than the schools in what they teach about human conditions, and particularly what they teach about schools. Social scientists must return to the core issues even when they are concerned with schooling. Human beings make themselves, and then remake themselves. This reproductive process requires that matters be taught, that matters be learned, and that some be learned anew. Particular languages, new skills, and new controversies must be taught and learned, and then taught and learned again as all the grounds shift. Each historical act—new technology, new governmental policy, or natural disaster-produces new forms of knowledge and ignorance that require changes in routines, even by those with the greatest interest in maintaining what will never be a status quo.

All this has been said many times but has not always led to the kind of research that fully respects the insights. To do so, I, along with other anthropologists exploring how to think about their work in educational term, start with the postulate that people, everywhere, unceasingly, and always in concert with others, work at changing themselves and their consociates through often difficult deliberations. ${ }^{4}$

This statement is, precisely, a postulate. It is not a statistical generalization. Rather, it is intended to direct our attention toward an aspect of human experience that the social sciences has rarely faced. In our work, we proceed through a confrontation between case studies and the theoretical frames that best account for the activity revealed in the cases. This article is designed to give a sense of this dual work, first with a review of 
some of the developments in social theory that we find most useful, then with a brief summary of a few of the case studies included in this issue, and then with a return to theory.

I start with "ignorance" treated, following Jacques Rancière, as a productive force. Then, I contrast two paradigmatic approaches to sociability that place at their core either learning or education. I move on to address a major stumbling block for social scientists considering education: Do social theories allow for "deliberation" as motor for social action? The following sections summarize case studies that illustrate both the practical research concerns that led us to our current position, and the yield of approaching the cases as instances of education rather than learning. The article closes with a further elaboration of the social theories that allow us to make the argument for placing "education" at the core of sociability.

\section{PRODUCTIVE IGNORANCE AND EDUCATION}

Let us return to the children at church. Let us assume that the girl, at the onset, is ignorant about whatever it is she is asking (she is not giving a school test to the boy). This ignorance is productive of an act practically affirming what is open to learning ("what is this [not that]?"). She sets the curriculum and authorizes the boy to teach. The boy, of course, is not compelled to respond in kind (though all research in conversational analysis suggests that even a refusal would have acknowledged the request as a request). Here the boy works with the delegated authority. He teaches about "this," and also about some of "that," but does not check that it is learned. The child then asserts the authority to close the sequence. ${ }^{5}$ And we now assert our own intellectual authority to develop the case, reveal our ignorance, and indicate how we might teach each other further.

There is nothing extraordinary about the children's work at church. It is a kind of work that can be found everywhere, even in the most oppressive settings. In this issue, for example, Grey Gundaker (2007) brings out the work performed by enslaved Africans in the Southern United States as they were able to read, write, and count despite continuing efforts to stop them. ${ }^{6}$ Again and again, the enslaved found various ways to teach themselves. Several of the other case studies in this issue similarly highlight the discovering, seeking, and controlling activities in which we find education. In all cases, people are brought together, often for specified institutional purposes-some well intentioned, and some less so. They often come of their own accord, but not always. In every case, we find people facing new forms of ignorance. And we find them dealing with 
this ignorance. So, in Hmong villages, in American college dorms, in Swedish audiologist offices, we notice moments when learning is at issue, but also teaching, setting the curriculum (what needs to be taught) and pedagogy (how it is to be taught), or authorizing who may do all this at any particular time. We notice the continuing work of all involved to do more than what is authorized-including the work of the powerful when their established authority is directly threatened. Above all, we notice the extent to which this work is discursive work, a matter of continuing deliberations both at the most local of settings when people meet face to face (say, to discuss what happened the night before at a party), and at the most global of settings when people set local conditions (say, when they discuss how to organize the delivery of health services, or the formal organization of a national polity). Not only is this work discursive in the sense associated with Foucault $(1975 / 1978)$, but it is also really meta-discursive; it is discourse about discourse triggered by the insufficiency of the earlier discourse-that is, by what I refer to as the "ignorance" that is the inevitable product of social life.

Emphasizing productive ignorance as a means to reopen the question of education is not as paradoxical as it might appear. In his work The Ignorant Schoolmaster, Jacques Rancière (1991/1999) wrote about a French revolutionary teacher of the 1820s and 1830s, Joseph Jacotot. Jacotot argued, in effect, that the best schoolmaster is the "ignorant" schoolmaster whose only role is to set the stage for a learning that he cannot control. To Jacotot, the master must be ignorant of the subject matter, otherwise he will impose his own understandings and thus stifle the freedom over which the revolutions of the late 18th century where fought. Jacotot was a pedagogue who was soon dismissed by those who laid the foundation of the modern school. Rancière is a critical philosopher who is elevating to a fundamental paradox all claims-whether made by Plato, Marx, or Bourdieu-to special knowledge of the knowledge necessary to understand social processes, particularly the construction of legitimate divisions within the body politic, or the critique of these constructions (Rancière 1983/2004). Our own task belongs to the world of the social sciences, but it takes seriously the same paradox: How do we get to know what is known by those whom we study? It is now easy to notice the fateful step that Oscar Lewis (1966) took when he claimed to know that poverty came from what the poor had come to know-that is, the "culture" of their poverty. How did he get to know that? How would we get to know something else that generations of critics have called for? We propose to address these questions by educating ourselves about the education that people give each other, and this must include, in our 
world certainly, the education that people give each other about what experts claim to know.

The overall work is something of a new beginning for us as anthropologists "of education." We have a keen sense of the scarcity of conversations within the discipline about education as a fundamental human activity. ${ }^{7}$ Our sense is that this scarcity is also characteristic of work in the other social sciences. This may be changing, as is revealed by recent exemplary work, a sample of which is included in this issue. ${ }^{8}$ I now develop our theoretical stance before illustrating its usefulness through a brief summary of some specific cases included in this issue. This development starts with a contrast between two authors emblematic of powerful traditions, Lawrence Cremin and Pierre Bourdieu.

\section{ALTERNATING ACCOUNTS OF THE RELATIONSHIP BETWEEN SOCIABILITY AND EDUCATION: CONSEQUENCES FOR SOCIAL SCIENTIFIC ACTIVITY}

Historian Lawrence Cremin and sociologist Pierre Bourdieu have little in common except that both found it necessary to challenge the common sense of their disciplines on matters of schooling. Each challenge made salient a set of problems. I am not interested in choosing an alternative, but in finding a way of accounting for the full range of the matters that Bourdieu and Cremin brought forth.

When Cremin started writing a history of American education, he found it inappropriate to make it solely a history of schooling in the United States. He began to ponder how to define education so that he could decide what to include in what would become his monumental History of American Education series (1970, 1980, 1988). This critical look at his own intellectual practice led him to write a series of papers (Cremin 1974, 1975/2007, 1976, 1978) in which he elaborated the definition quoted in the epigraph to this article: Education is "the deliberate, systematic, and sustained effort to transmit, evoke, or acquire knowledge, attitudes, values, skills, or sensibilities, and any learning that results from the effort, direct or indirect, intended or unintended" $(1978,567) .{ }^{9}$

Bourdieu came to schooling and learning on a reverse trajectory. $\mathrm{He}$ started as a sociologist and critic of modernity and then found it necessary to face schooling — that is, "systèmes d'enseignement institutionalisés"-as the central $\operatorname{cog}$ in the reproduction of social inequalities. In a fateful analytic move, he then asserted that the power of schooling is based on a set of mental dispositions, the habitus, so constructed as to prevent discursive awareness ("reconnaissance") of its most violent properties. Schooling, once established, reproduces this habitus across the generations. 
Bourdieu thus established his social theory on postulated moments of deep learning and the consequences of a form of learning that is not accessible as, precisely, the learning of a "cultural arbitrary." Starting with broad issues of cultural patterning, social organization, and a concern with practical activity, he came to place the school as key to the reproduction of class segmentation (1970/1977) and its "cultural" aspects (1979/1984). Whereas Cremin traced the diachronic transformation of the school and its contexts, Bourdieu emphasized the synchronic "arbitrariness" of schooling as a method for moving the young into adult positions within the modern polity. He also emphasized the violence that must accompany the imposition of any culture on a new population of human beings. He analyzed schooling as a set of relationships among controlled and controlling agents (teachers, parents, students). These agents of the school use particular methodologies (pedagogies), rely on specific forms of authority (to teach and to evaluate), and themselves depend on particular forms of legitimacy. He is most famous for such provocative statements as:

Given that it explicitly raises the question of its own legitimacy ... every ES [institutionalized teaching system] must produce and reproduce, by the means proper to the institution, the institutional conditions for misrecognition [méconnaissance] of the symbolic violence which it exerts, i.e., recognition [reconnaissance] of its legitimacy as a pedagogic institution (Bourdieu and Passeron 1970/1977, 61).

Schools "inculcate" the re-cognition of their legitimacy and the miscognition of their violence. That is, in its practices, "every ES"-what we refer to as "the School"-must rely on, as well as induce, a particular form of cognition with emotional correlatives. The School, if we are to accept the analysis, is mostly successful at it. In fact, it must be successful, otherwise the whole arbitrary construction would collapse. ${ }^{10}$ Bourdieu's accounts require a learning theory, but he never specified what it would look like.

By contrast, Cremin's accounts do not require a theory of learning, but they require a theory of deliberation. He demonstrated that, continually, everywhere in the United States, and among all the social groups that kept appearing on its shores, how to educate was a perennial question. Schooling emerged and became a dominant form, but it was always at play from every point of the political compass. Rather than disappearing into the "natural," the particular forms that temporarily seem to characterize "American education" are always brought to awareness. The 
history to be written is one of controversies, apparently settled in institutions producing new controversies in a cycle that is far from over. To account for all this, Cremin did not hypothesize the sharing of habits, for nothing stayed habitual for long. His concern was with coparticipation within shifting fields and the consequences of such coparticipation. For Cremin, sociability requires deliberate and systematic efforts to figure out what is going on and convince others about what to do next. Sociability requires education because the efforts to change consociates never stop.

Cremin thus challenged a century of theorizing that makes the evolution of humanity dependent on unconscious processes presented as the "root causes" of various states of affairs. Against many historians of his generation, he did not seek to "explain" developments, particularly unwelcome ones, by linking them causally to other developments, particularly in the economic sphere. Capitalism, or the power of entrenched elites, cannot account for the progression of the conversations that produce the precisely arbitrary institutions that people end up living with. It is not that capitalists or powerful elites are not always agents in the shaping of these institutions, but that they are not the sole of even prime movers. ${ }^{11}$ This refusal to explain has been taken as theoretical weakness and political naïveté-unless one pays close attention to Cremin's intellectual practice. There we see him concerned with debate, doubt, skepticism, imagination, and controversy about what to do next. To this extent, and by implication, Cremin's work prefigures much recent work on resistance and agency. Above all, it is a challenge to grand theories when they do not directly face uncertainty, ignorance, and the seeking of practical knowledge.

When he was writing, Cremin's implicit theorizing stood out as odd. He seemed to stand against the most powerful frameworks of his time, whether drawn from Marx or from the Parsonian integration of Weber, Boas, and Freud. Thirty years later, Cremin makes more sense given the multiple critique of all Parsonian frameworks, particularly those coming from ethnomethodology, and the tweaking of Marxist discourse evident in Lave's recent work (Lave and McDermott 2002). In his expansion of ethnomethodology, Garfinkel (2002) now emphasizes the monitoring for trouble, instructing, and moving on that he finds everywhere he looks. Garfinkel is pushing the implications for research of the now common sociological sense that all social action is improvised, difficult practice in strongly framed, though indeterminate, settings. Garfinkel also insists that action is work, an echo of Cremin's insistence on "effort." The second development can be found in Lave and Wenger's work (1991). Lave is known for a "learning" theory. Unhappily, this theory is often taken for a theory of how things get to have been learned in the past 
experiences of individuals. We take it for a theory of ongoing activity driven by the publicized ignorance of those who are deliberately placed in "peripheral" positions. This activity is conducted in social fields ("communities of practice") that are powerfully differentiated by complex asymmetries that drive movement across the fields. As Lave and Wenger (1991) put it, "mastery is an organizational relational characteristic" (64). Mastery is not a property of the person and is not based on whether the person has learned; mastery is something that comes to exist after some form of public acknowledgment, what Mullooly (2007) calls "regradation ceremonies." Determining under what conditions a person can be said to have moved (or not) across various boundaries is major work for the "communities" or, as we prefer to say, the "polities" that catch individuals into their mechanisms. ${ }^{12}$ As Lave and Wenger put it,

Hegemony over resources for learning and alienation from full participation are inherent in the shaping of the legitimacy and peripherality of participation in its historical realizations. It would be useful to understand better how these relations generate characteristically interstitial communities of practice and truncate possibilities for identities of mastery (42).

We return to Lave and Wenger, and Garfinkel in the conclusion to this article. Eventually, they provide the best justification for using the word "deliberate." Many among Cremin's readers have found this word difficult. We now address these difficulties.

\section{ON DELIBERATE EFFORTS TO WRITE ABOUT EDUCATION}

In a wonderful analogy, Gregory Bateson (1972) proposed that social action is akin to the fantastic game of croquet that Lewis Carroll (1871) imagined, in which mallet, ball, and hoops are all alive and moving in unpredictable directions. In this game, the (cultural) facts of croquet have not changed; neither have the (biological) facts of life. Both must be taken into account when they become related at any particular moment. But neither set of facts, however well known, is much of a guide to Alice as she wonders how to hold flamingoes in order to hit hedgehogs. It is tempting to think of Alice's confusion as if it concerned only a moment of personal "deliberation" as she seeks to learn how to handle a new situation. But Bateson is not primarily interested in the psychology of the learner; he is interested in the interaction of all those who place Alice in the situation of having to develop a particularly implausible skill (and then makes the learning irrelevant). He makes us face the dance 
and leaves us to wonder about the dancer. In the same spirit, if Cremin were writing the history of that moment, he would write about the Queen who set the game up, the guards, and everyone in danger of losing his or her head. He would have mentioned how hard it all was for all involved, but he would not have tried to characterize the personal makeup of those who struggled, whether they were immigrants trying to figure out American schooling or John D. Rockefeller funding the University of Chicago. The history of American education cannot be a history of persons but a history of the evolution of the settings (dances and dangerous games) within which all have to perform.

Cremin must have been aware of this when he wrote the first sentence of his definition with no personal subject at all: "education is..." By the second sentence, one gets a sense of who or what may educate: "parents, peers...families...factories" (see epigraph, Cremin 1978, 567). Cremin focuses our attention on the organized efforts of small collectivities framed by broader institutions. The subject of educational deliberation is human, not personal. Education is a conversation among those who have been made "consociates" as they must face, together, potentially dangerous ignorance, and as they must then figure out what to do next with a host of "others," from babies to immigrants to aging parents, who are about as predictable within set fields and rules as flamingoes and hedgehogs.

It is a fact of English that the paradigm of words that include "deliberate," "deliberation," or "deliberative," of course, can be dangerous to one's intellectual practice. To the extent that the word refers to the private activity of a separate person rationally weighing alternatives on the basis of earlier knowledge, it cannot apply to what we are trying to do. The word "deliberation" fits our bill to the extent that it applies to the joint activity of people talking about something that happened outside their immediate setting; making practical decisions about what is to happen next; and then publicly reflecting on what just happened. The prototype for such an event would be the deliberation of a jury at the end of a trial. Friends talking about their lives are also deliberating; that is, like the college students in Portia Sabin's (2007) case, they are doing something deliberate that involves deliberations. Complex polities deliberating about the best way to deliver new types of medical procedures are also educating themselves. ${ }^{13}$

There is another danger in the use of words like "deliberation" to the extent that they call to mind their opposites and thus reconstitute an old, tired, and inescapable dichotomy. Cremin, for example, was working within this dichotomy when he wrote about "incidental" versus "intentional" education. ${ }^{14}$ But he was well aware of the need to challenge the 
dichotomy. ${ }^{15}$ In Public Education (1976), Cremin systematically criticized John Dewey for not keeping to the sense that education is a general human principle not particularly linked to any institution. Schools may be one setting through which America builds "democracy," but the media, religious organizations, clubs and associations, and so on, may be more powerful. And they are not really "informal" institutions dispensing "incidental" education. It may even be the case that the more salient schools are as political institutions, the more powerful are those (e.g., politicians debating vouchers or the teaching of evolution) who educate the polity about schools. Cremin would not agree with Illich (1970) that schooling always stands in the way of education, but he kept affirming that education is a process in its own right. Education subsumes culture and politics, the informal and the formal, the incidental and the intentional. It breaks the polarity. Still, to make the challenge is not quite to answer it, and the various programmatic calls made by Cremin and those who worked closely with him (Leichter 1975, 1979) have remained mostly unheeded. ${ }^{16}$ And so, with him, we ask again, deliberately and in deliberation with colleagues and peers, What are we to study when we study "education"? Where do we go? What do we notice? When is "education"? The following overviews of the case studies included in this special issue start answering this question. Then is education when Africans, brought to the Americas as slaves, discover European literacy; when Hmong girls ponder the peculiarities of Thai modes of identification for them; when Jordanian girls and their teachers face multiple strictures about music, their State, and Islam; when American college students discuss their sentimental affairs; when school officials fear the loss of their reputation; and when national polities discuss museum exhibits in the United States, health care policies in Sweden, or the legal representations of difference in New Zealand/Aotearoa?

\section{FINDING OUT THE FACTS OF CULTURAL LIFE AND BUILDING PERSONAL CAREERS OUT OF THEM}

Let us push all this by looking briefly at three instances of humanity at work with clothing and language, music and religion, and friendship and love. All are taken from papers in this issue:

The example that seemed to cause the most concern was how to translate the Hmong word Kuv, meaning "I," into Thai. The question was, "How do I say Kuv in Thai?". . .? This question arises in part from the fact that the Thai language system maintains a great deal of complexity in its self-reference system . . . . 
When speaking in Thai one must make a choice between a number of different self referents, the most common for a student being $n u$ (mouse), nong (younger sister/brother), their given name, or finally chan/pom (a form of "I" depending on whether the speaker is a girl/boy). However, it is not so much the individual student who makes the choice of which self referent to use, but rather it is up to the student to understand the complexities of the social situation in terms of how it defines her within the context of other speakers. (Johnson 2007)

And again:

Fida Adely: Do you face any problems because people have the opinion that music is a bad thing?

Hannan: We hear this kind of talk a lot. For example, the other day the computer teacher got a hold of me and said "Don't you cover your hair? So why music?" [Hannan continues,] "But I am not that committed [i.e., religiously]. Should I tell her I am free to do what I want? That would be rude. She will say, "Why do you go to music? Music is haram."

Fida Adely: How do you react to her?

Hannan: I try to take it lightly and joke so as to pull myself out of the discussion.

Farial: So that there won't be problems between you and the teacher.

Hannan: Then we go and tell our music teacher, "This teacher said this, this, and that."

Farial: We just ignore it. We know what we are doing and music is fine. We listen to music at home.

(Adely 2007, pp. 1663-1681)

Or again, paraphrased from Sabin (2007):

On a Friday night, in a small college in the Pacific Northwest, all the residents of a coed dorm floor were assembled to have fun. They played "Truth and Dare" and, during the game, on a dare, 
Jenny kissed Ed (and at least one other boy). Over the following weekend several conversations about Jenny and Ed occurred. They involved at least four more persons: Hanna, Kat, Michelle, and Portia Sabin herself [the anthropologist]. Should they tell Hannah that Ed had kissed Jenny? Are these the kinds of things one tells? What might be the consequences?

Paying attention to moments like this raises all the issues that we started reviewing with the case of the little girl in church: there is the recognition of ignorance that might be alleviated by talking to others; there is potential learning; and there is continuing uncertainty as the new knowledge proves to be as unhelpful for dealing with the world as Alice's knowledge of the rules of croquet left at loss when trying to hold flamingoes.

We are concerned, above all, with human uncertainty when confronted with all the facts of their lives, including the facts produced by other human beings over the course of the history that leads particular people-in the United States, Thailand, or Jordan-to face particular issues. We are concerned with the moments when people find out about the facts of their lives, when others remind them that these are the facts, and when people enforce various properties of the facts. I write "find out," "are reminded," and "enforce." I do not write "learn" (or "teach") to allow for the discussion of a more fundamental process. We are concerned with the practical consequences of the factuality of the social world, and specifically with (1) the experience of this factuality; (2) the attempts to tell this experience through one of the facts of all human beings' lives, their language, its rhetorical forms, and the social organization of any telling, ${ }^{17}$ and (3) the attempts to convince others and then move them in particular directions even as they resist the attempts.

To explicate this, let us focus on growing up in the United States, the background for Sabin's research into everyday life within a college dorm. Let us assume that in the United States, children, as they turn into adolescents and then adults, are confronted with images and discourses of "love" (friendship, fun, and so on). At church, on TV, in the movies, in the music they identify with (and the music of other generations and groups that they do not identify with), and even perhaps in school, love will appear as something somehow relevant to all people's lives and thus, somehow, to theirs. This, I would say, is about inevitable. ${ }^{18}$ What any particular person learns about all this is another question altogether. I would imagine that it will vary a great deal, not only depending on the obvious categories (e.g., gender identification, race, and ethnicity ) but also on the less obvious ones (e.g., physical attractiveness, intellectual interests, and religious fervor). 
Finding out and then deliberating about love are activities that must, I am convinced, be distinguished from learning about love. This distinction is particularly necessary to account for the moments when abstract knowledge confronts everyday practice. Let us assume that an adolescent (or an observer of adolescents) could summarize "what I (he/she) have (has) learned about love in America reading novels and going to the movies while listening to popular music." ${ }^{\prime 19}$ What Sabin (2007) illustrates is that this knowledge may not be very helpful at the very moments when it should be most helpful. "What to do next" to maintain or end a relationship is certainly not a matter of applying a rule, nor even developing a strategy; it is a matter of deliberating with those who become involved as the relationship is publicized. Sabin describes the giving of conflicting advice, coercion, and justification. In these conversations, the participants slowly change each other's lives. They teach, they probably learnand not only about friendship or love but also about college, adult relationships, and the limitations of friendship. This process does not end. Whatever "has been learned," as it might be summarized at the end of any period, will again prove of limited use as the students move from college dorms to the towns and cities of the rest of their lives.

To the extent that literacy is a cultural fact and involves much more than "knowing how to read," then the same points can be made. For many people in the world, the basic question is settled very early on and is not open to much discussion. But for many more, literacy remains, as it was for generations over the past centuries, something that adults must discover as a continually new puzzle to ponder with those who make it necessary, those who enforce it, those who use it for any number of nefarious ends, and those who advocate for it. As reported by Gundaker (2007), for the Africans who arrived as slaves in the Americas, the literacy of the elites among Europeans was an occasion for education even before some of them found out how they might actually "learn how to read" and deal with being forbidden to do so. Something similar is happening to illiterates in places like the Brazil that Bartlett (2007) reports on.

\section{EFFORT, INSTRUCTION, TRANS-FORMATION}

In the full account of her research (2004), Sabin gave extensive information about the efforts that the students made to transform each other's lives. They were not simply "being students" after learning how to be a student. Or, rather, "being a student" — in real, ongoing life-is precisely the matter of making the educational efforts that one sees the students make as they deal publicly with what they cannot escape. Similarly, slaves, Hmong girls, and Jordanian adolescents reveal what is most salient to 
them: being enslaved, ashamed, made to speak a foreign tongue, to worry about singing. In all cases, participants improvise with and against the terms of those around them who may have more power than they have in setting up these terms and enforcing them. ${ }^{20}$

These last statements were written in the style of Garfinkel's ethnomethodology $(1967,2002) .{ }^{21}$ At the core of Garfinkel's sociological imagination is the sense that all human beings, all the time, must discover again and again what is happening around them. Human beings must be practical sociologists using an "ethno-methodology." This built on the demonstration of the limitations of social theories that relied on the sharing of knowledge. ${ }^{22}$ Social life is not about storing knowledge, but about getting others to act. For this purpose, it would be foolish for a subject simply to rely on acquired knowledge without continually checking for what is now important for the interactional others, and also revealing to them what is important to the first subject. At the moment of action, one is always confronted with a mystery: What is this? Who is this person? What on earth are they trying to do? There is now an extensive body of research revealing how much work is performed by people in the most familiar of situations as they check that everything is in fact familiar (on their way to making something not familiar). In recent years, the logic of this argument has led Garfinkel to become interested in the "instructions" that people must be giving each other, precisely because it is too risky, in everyday practice, to rely blindly on sharing. Human beings also need an embedded "ethno-pedagogy," as we might call routine instructional work.

Garfinkel (2002) starts his exploration of instructional acts with "instruction manuals." He demonstrates that it is impossible to write the exhaustive set of instructions that these manuals sometimes claim they provide. To be exhaustive would require taking into account everything that human beings might do with the instructions, in the future of their personal lives, when they practically analyze the objects in front of them, including the manual, the unassembled pieces, and other matters in the assembler's environment (including other people). This future is precisely unknowable..$^{23}$ But this uncertainty is precisely what makes instructional acts ubiquitous. Thus, Garfinkel moves on to various experimental or quasi-experimental settings where he investigated how people ask and receive instructions when they are deliberately confused.$^{24}$ And he gives us the case of Helen, legally blind, who greets guests coming into her house for the first time with a "Please stay out of my kitchen!" (212-16). Helen has deliberately organized this kitchen so that she can take for granted where every object is located ${ }^{25} \mathrm{~A}$ sighted person will not recognize this enabling construction and will move objects, making a host of 
new problems for Helen. We have here deliberate instructions about instructions, first in the attempt by Helen to instruct herself about her world and shape it so that she can live within it, and second in her attempt to teach her guests what they must do not to handicap her further. Nothing of this can stay below discursive awareness.

Garfinkel makes several theoretical and methodological points relating to the facticity of the conditions in which people find themselves. We pursue only one that brings us back to the most classic problem for education as it was, for example, phrased by Dewey in Democracy and Education $(1916 / 1966){ }^{26}$ Dewey, like generations of social scientists after him, proposed that social orders ("democracy") are maintained through acquired shared understandings. Bourdieu agreed, though he emphasized the violence of the means that must be employed to reach what he would deem shared mis-understandings. Garfinkel disagrees with both: social orders are maintained because of the instructional work that everyone involved performs-everywhere (not only in schools) and continually (not only in the early years). This is a distinct development on the first versions of his ethnomethodology and worth exploring further because it is central to our own argument about the ubiquity of education.

This instructional work is particularly noticeable when one does something taken as a threat to the constitution of the order. Garfinkel (2002) gives one apparently simple-minded example. He looks at people standing in line for some service (e.g., getting stamps at the post office). Such a line is a social fact, and an "immortal" one at that (chap. 8). It persists as a line even as individuals move in and out of it. But the line is also the product of the deliberate work of those involved while they are in line, including the work of maintaining the interactional boundaries of the relevance of the line. During this demonstration, Garfinkel states, "Consider that once you get into line persons will not therein question that you have rightfully gotten into line unless you start screwing around. Then you get instructed" (257).

Not so obviously, "screwing around" is only possible once one's behavior has been made relevant to the line as constituted by the usually invisible work of those in the line. ${ }^{27}$ As Bourdieu rightly noticed, an uneventful line is not the product of a "rule" that people follow, but neither is it the product of a "disposition" (habitus). It is the product of the continual instructions that people give each other as they work at moving each other uneventfully (through a line, a dinner party, a class, years of schooling, medical procedures, and so on), and changing each other if this proves necessary. "Common sense," then, is just the temporary absence of instruction about what to do next.

Routine instruction may not appear particularly "educational" in the 
humanistic sense. And yet, Garfinkel, like many before him, constructs a theoretical subject who is fully active as a distinct human being. This subject is an active seeker continually obliged to leave aside earlier knowledge and habits to deal with the real conditions now standing in the way. This subject is a bricoleur (Lévi-Strauss 1962/1966), enunciating a life (Merleau-Ponty 1969/1973; de Certeau 1980/1984) in concert with a host of others, sometimes helpful, and often threatening. The subject, again and again, is made ignorant of that which may make the most difference at any particular moment, and must thus, in a true humanistic sense, start seeking again. The subject is also one who "screws around" or, in other terms recently proposed, the subject (deeply) plays, extravagantly. ${ }^{28}$

\section{EDUCATING MODERN HUMANITY ABOUT EDUCATION, HEALTH, AND POLITICAL ORGANIZATION}

Ethnomethodology has been criticized for being solely concerned with the activities of individual agents in the real time of their face-to-face interaction. We take the position, and present evidence, that all we have said so far also applies to institutional agents as they elaborate what will become the cultural facts of life for many. Institutions also play deeply when they elaborate the frames within which those whom they serve and control will then have to act. They who are responsible for schools, museums, hospitals, and parliaments are regularly made to notice that the people they are attempting to deal with "commonsensically" on the basis of earlier and, it is hoped, "shared" understandings, are actually screwing around to such an extent that the old instructions do not quite work anymore. And so they must deliberate, in renewed ignorance about the people they are responsible for (or claim responsibility for), to produce something new-even if the goal is to return to a status quo. From our point of view, controversies fought on national stages about major institutions must be approached as educational.

Four of the case studies in this issue explore the issues. I summarize two to clarify the argument. The first deals with the relationship between museum curators and those who visit their exhibit. The second deals with various political actors attempting to transform fundamental properties of their nation-state.

Anne Lorimer $(2003,2007)$ illustrated the variety of responses triggered by a technology museum exhibit featuring a full-scale airplane. This exhibit was very deliberately and carefully set up by curators with a complex discourse about what they hoped to control (the properties of an "effective" museum exhibit), what they imagined (the properties of 
the "urban" populations that the museum serves), and a host of other matters that they could not quite control (the architecture of the museum, the properties of a "real" airplane, insurance fears). In the process, they produced something that was not quite what they had started planning to do but did in fact become a puzzling fact for their visitors. For example, they decided to cut holes in the floor of the plane to show the landing gear, something that is precisely not accessible in an actual flying plane. Lorimer then moved to give us a sample of the responses of those who entered the exhibit, conversed about it among themselves, and produced much that the curators neither expected nor wished for.

Ilana Gershon (2007) takes this further in her work on the challenges that new migrants pose to those with the authority to represent constitutionally the nation-state variously known as "New Zealand," "Aotearoa," and "New Zealand/Aotearoa." This multiplicity was built on the encounter between the British and the Maori and the evolving interpretation of an 1840 treaty between people claiming authority on both sides. In recent years, this has led to New Zealand as being seen as bicultural state. This is expressed in all sorts of public documents that govern, among other things, the kind of performances on which Gershon focuses. These documents, like the original treaty, appear as closing statements to long deliberations: they "celebrate" what is now a fact. But the very same statements now trigger new controversies from all sorts of points of view, particular from Samoans and others as they enter the political sphere and ask for a different kind of identification from the one they are offered.

In brief, Samoan immigrants, like museum visitors (and the old ladies with hearing loss, and the successful kids vandalizing cars who also appear in these pages), "screw around," and they do get instructed. Certainly there is a difference of scale here as hundreds, thousands, millions of people get involved. Our sense, however, is that the analytic process should remain the same. To account for the details of the performances in the real time of their historical unfolding, one must focus intently on the every renewed uncertainty of all, including the most powerful, as they seek what to do next, and explicate it to each other and to all those over whom they may have some authority.

\section{EDUCATION AND PRACTICAL POLITICS}

At the national scale, of course, local instructions are never enough, particularly when the infractions continue and get ever more elaborately publicized. Consociates never quite go back to where they were before 
the instruction sequences, if only because these sequences have themselves become part of the public history of the polity. Instructions about instruction move us fully into the realm of the deliberate, and deliberative, and thus the politic. What is to be gained by investigating political struggles as educational processes will remain open to questioning. But it is worth exploring the further possibilities opened by refocusing our lenses. The object is not to sort out what, in human behavior, is "political" by contrast to "educational." All acts must be both, at the same time. This is particularly the case if one accepts de Jouvenel's approach to politics as summarized in a statement that is an eerie echo of Cremin's (1963/1977) definition of education:

I hold the view that we should regard as "political" every systematic effort, performed at any place in the social field, to move other men in pursuit of some design cherished by the mover. According to this view we all have the required material: any one of us has acted with others, been moved by others, and has sought to move others (38-39).

It is to signal the congruence of the two approaches to action and movement that I suggest we rewrite Lave and Wenger (1991) and move from using the word "community" to using the word "polity" in their famous phrase. It is an American fact that the word "community" is dangerous for American intellectual practice. Most important, the word "polity" highlights the point that Lave and Wenger make repeatedly: "learning" is political because it is social-that is, public. Conversely, political practice must always involve not so much "learning" as the kind of public deliberations about conditions that all the case studies in this issue bring out.

Education/politics is about necessary movement across organized social fields, and it is about inevitable change to these social fields. Approaching humanity in terms of education/politics is the only possible way to face the impossibility of replicative reproduction. Human beings die, others are born. Newborns must be moved to full authoritative participation. But the very means available, to the very extent that they are matters of education and not inculcation, ensure that the grounds of participation will shift and that new "difficult collective deliberations" will be triggered.

Like Cremin, Lave and Wenger, Garfinkel, and others, we are not saying that "learning" in the usual, individual sense has not taken place when these deliberations apparently end. But we leave this to psychologists to determine. Our concern is with the new laws that get passed, with 
the administrative regulations that get rewritten, with the people who marry and must now make a completely new life for each other and many of their friends and relatives, or with what those who are now able to read actually do with their new skill. By the time an educational sequence has ended, the polity has moved on, and those who now enter it must wonder about what are now the facts of their cultural life and restart all deliberations. Whatever was learned is now mostly moot; it may have to be unlearned; it is time for education. The real life of real human beings as they encounter their real, material conditions may or may not produce measurable learning inscribed in their bodies. What human beings cannot do is rely on this learning. Life requires education.

There is, of course, a very dark side to all this. The determined effort to transform the conditions of consociates can leave them in a worse position..$^{29}$ This is particularly the case when this effort is conducted by people with strong delegated authority to make this transformation public. Teachers and others in the realms of schooling are in this position, or those in charge of diagnosis in the realms of health care. Mehan, Hertwerk, and Meihls (1986), McDermott (1993), and others (Lave and McDermott 2002) have repeatedly noted that those who establish school merit are not bound by the rational evidence of learning to move those for whom they are responsible across any number of boundaries, or to block their movement. But the problem is made even worse when one attempts, as generations of researchers in applied cognitive psychology have done, to increase the validity of the rational evidence and ever further to work politically to ensure that this evidence is binding on professional gatekeepers. In simple terms, the more focused and sensitive they are to a person's particular skills and knowledge, the more they can document that the person does not know something. If that which one has been shown not to know is deemed essential to some social good, then one must be the object of efforts to cure the "disability." The "better" the test, the less will the subject be able to escape the public label.

Even the apparently symmetrical discussions of the college students about their sentimental relationships may turn uncomfortably coercive. "Peer pressure," as Sabin (2007) shows, is an everyday practice. At a different scale, and in a different register, Mullooly (2007) questions whether the "success" of a middle school in terms of the placement of poor immigrant children into elite high schools is a matter of the strength of its curriculum and pedagogies, or whether it is a matter of the management of its reputation with the high schools it needs to feed into to demonstrate this success. Like any other form of movement to celebrated full participation, it may be more a matter of "passing as" than of "being," a matter of "collusion" rather than acknowledgment of "reality." 
Whatever the perspective, all these approaches to knowledge as social practice suggest that the exact place of "learning" (as that which has been learned) and "ignorance" (of what might have to be learned) is fundamentally unspecifiable. The only thing that is specifiable, because we can observe people specifying it to each other, is where they place themselves and each other in relation to knowledge and ignorance. We started with one little girl specifying what she did not know, thereby revealing her knowledge of what might be learned. We end with the Hmong girls from Johnson's case (2007) who ask the American expert, "How does one say 'I' in Thai?" and then discuss a most significant difference between two languages with very different means for indexing the speaking person. Like her, we who participate in the endeavor introduced in this article do not take such situations as instances of brewing intercultural trouble, but rather as the reverse: the girls in Thai/Hmong schools, like the adolescents in Jordanian high schools, like the young adults in American college dorms, are confronting a pragmatic difficulty, developing a metapragmatic discourse, and powerfully educating themselves in the most liberal sense. Whether this will make them successful in the terms to which they will be held accountable is something else altogether.

We believe that all researchers must postulate that all people are like these girls, wondering what one might do with a previously unnoticed object in one's environment. Only with such a postulate will it be possible fully to acknowledge the struggles of those we study and to recognize practically that our own work does not belong to a different realm of human activity. But we, as researchers, cannot put ourselves outside, for our work, if it has any impact, may become an object of wonder. McDermott (2000) reminded us that Margaret Mead liked to say she "came to help." Educational researchers and other applied social scientists like to take the position of well-intentioned friends deliberating on how to help. But we must fear that, as happened to blind Helen when her friends "helped," we may also further handicap. The more authority we are given to develop new health care delivery systems, or new curricula, the more we should fear ourselves. But our power is never absolute, for people like Helen-like all little girls, students in dorms, the aging-will never stop educating themselves about us. In any event, we have no choice but to persevere, focus on our ignorance, propose new accounts and policies, and educate.

\section{Notes}

$1 \quad$ Making the two synonymous has in fact been the goal of at least two centuries of a kind of social engineering that has attempted to capture and control the fundamental activ- 
ity for particular state purposes, including the unimpeachable purposes of building a democratic polity, making the tools of high culture available to all people, and equalizing chances. This development has been globally successful, and it is not surprising that schools should now appear the paradigmatic educational institution, or that researchers of education should focus most of their efforts on schooling and its specific problematics.

2 The verb "constitute" is rooted in ethnomethodological usage but is intended to go beyond this usage. "To constitute" is a stronger verb than the verbs "make" or "construct" that have become popular in educational research. The verb "constitute" emphasizes the political aspect of joint human productivity. This line of argument, including the justification for the capitalization of the word "School" in certain contexts, was started in Varenne and McDermott's Successful Failure (1998). This footnote is developed on the Web at http://varenne.tc.columbia.edu/hv/clt/issues/constitution.html.

3 This does not mean, of course, that religion, popular culture, etc., are not taught/learned in schools. It just means that we cannot ignore analytically that some of this teaching/learning is heavily sanctioned by the institutions framing the School, from faculty in schools of education proposing new reading programs, to the Supreme Court.

4 This approach, it must be stressed, stands quite distinct from the usual anthropological definitions of "education... as humanity's unique methods of acquiring, transmitting, and producing knowledge for interpreting and acting upon the world" (Levinson 2000, 2).

$5 \quad$ Naddeo and Varenne (Naddeo 1991; Varenne and McDermott 1998, chap. 3) have reported at length on a very similar case of education in the midst of other activities. In all these cases, much of the interaction works deictically-that is, in terms of such indexes as "this," "that," or equivalent gestures.

6 See also the rest of Gundaker's work on cultural productivity among the poorest in the Southern United States (1998, forthcoming).

7 The decision of most anthropologists of education to address the problems of "educationists" and the success of anthropological approaches among the latter have conspired to produce a situation in which most of the research work in the field focuses on schooling. The leading journal of the subdiscipline, the Anthropology and Education Quarterly, published 37 papers in 2002 and 2003. Of these, 26 are about schools (16 in the United States and 10 outside), 6 are related to schooling, and only 5 directly confront processes not related to schooling. This has not prevented some anthropologists from arguing that the field ignores schools (Levinson 1999). We side with the reverse criticism that emphasizes the price to be paid by the attempt to address directly those who have been building the public school, evaluating it, and reforming it. One has only to look at various reviews of anthropology and education in the 1970s and 1980s (Bond 1981; Kimball 1974; Calhoun and Ianni 1976; Lindquist 1971; Pelissier 1991) to realize that anthropologists have known that their work was in the streets (and the dorms, policy centers, and so on). Liberian tailors (Lave and Wenger 1991), Yucatec midwives (Jordan 1989), college students worrying about their intimate relationships are not simply "interesting"; their activity is what should be at the core of any anthropology of education. But it is not self-evident that the work of Lave, Jordan, or any of the others has much to contribute directly to a political concern like "achieving greater equity in American schools." Demonstrating the relevance of anthropological work while not getting caught by the terms of the political discourse is something that remains to be done. And so, as John Singleton (1999), among many others, reminded anthropologists recently, "the critical confusion of education with schooling continues to bedevil us" (457) - as it has from the first papers in the American Anthropologist that talk about anthropology "and education" (Hewett 1904, 1905), through the great classics (Boas 1962; Lynd and Lynd 1929/1956; Henry 1963; Spindler 1955).

8 One should also look at Neriko Doerr (2004), who has brought forth the work of 
Samoans and others in New Zealand as they confront the state on the matter of the available ethnic identifications. Mica Pollock (2004) showed how difficult it is to talk about race in schools (2004), and Ingrid Seyer-Ochi traced the conversations of urban youths about school and the street (2002). One could also look at the work of Mexican migrants who devise ways to teach each other English by developing what Tomas Kalmar called "illegal alphabets" (2001). Verrips and Meyer (2001) gave us the case of the reconstruction of a car in Ghana; all the parts but the body had been improvised and put together by people with no access to the official channel for mechanical expertise. And most of the work assembled by Daniel Miller in recent years (1993, 2001a, 2001b, 2001c) could be reinterpreted as work in education and popular culture.

9 This definition actually picked up an earlier definition by anthropologist Cora DuBois (1955): "Education is both the deliberate inculcation of knowledge, attitudes, and values and the unconscious transmission of modes of perceiving the world" (91). She introduced this definition, as Cremin would do, as a tool to distinguish between school and nonschool processes.

10 In many ways, Bourdieu rewrote Parsons and Shils's "theory of action" (1951) with a much greater emphasis on the arbitrariness of social forms and the violence of the means used for preservation and reproduction. The links between Bourdieu and Boasian cultural anthropology are also quite strong, not only because of the emphasis on arbitrariness and integration of the means establishing a particular cultural arbitrary but also because of his emphasis on the learning of the core generative principles of this integration. For more on the overall critique of Bourdieu and those who work with his theory of habitus, see Varenne and McDermott (1998, chaps. 6 and 7).

11 The story of the evolution of schooling is also the story of the resistance of elites to what was being proposed. It might also be written as a history of the cooptation of institutions that the elites could not destroy. An argument can be made that the work of entrenched elites, particularly in liberal democracies founded on ideals of equality and meritocracy, is mostly subversive-once their oppositions to the establishment of revolutionary ideals is defeated (see Varenne and McDermott 1998, chap. 5). It would be worthwhile to look at what generations of school critics have written, more as a critique of how schools have been misused than as a critique of schooling per se.

12 In the United States, the word "community" is too profoundly ideological to be used as a theoretical word.

13 It would not be a stretch to argue that any instance of metapragmatic discursive activity, particularly when it is directed to transformation, might be approached as educational (Jakobson 1960; Silverstein 1993; Wortham 2006).

14 Researchers often distinguish formal and informal processes. It is a comfortable polarity because it somewhat maps the distinction between culture and politics. In culture, participation "naturalizes" what is constructed in history. This process can be qualified as both incidental and informal, and collapsed into the domain of enculturation best left to social psychologists. In politics, the powerful determinedly construct what will maintain them in position, and the weak resist with whatever weapons they can find. When dealing with the modern world, the dichotomy gives a practical justification for collapsing the study of education into the study of schooling.

15 Check, for example, Greenfield and Lave's (1982) discussion of their use of the word informal.

16 Chere have been notable exceptions: for example, Taylor and Dorsey-Gaines (1988) on literacy in inner-city families, and the more recent work included in the volumes edited by Eve Gregory and colleagues (2004), Jabari Mahiri (2004), and Jim Anderson and colleagues (2005). I am deliberating leaving aside such work as that of Lareau (1989) on 
"home advantages," or Moll and colleagues on funds of knowledge (2005). Both their work and that inspired by their work do index the reality of family education but, to the extent that it gets to families through schools and their problematics, they do not tell us much about education specifically within the family and in terms of particular families' problematics.

17 I am strongly influenced here by Merleau-Ponty's argument about turning the world into prose (1969/1973).

18 Imagining the conditions under which some people in the United States would not be confronted to "love" is an interesting intellectual game in what it might reveal about the limits of participation.

19 Of course, as Garfinkel repeatedly demonstrated, such a summary is impossible as a matter of sociological principle.

20 See Klemp et al. (forthcoming) on jazz improvisation.

21 Note that my approach is an expansion of most ethnomethodological accounts of its own work to the extent that I emphasize the arbitrariness of the conditions revealed in the deliberate efforts of all involved. I also emphasize social structural differentiations among those who have become consociates, whatever their personal take on the position to which they must relate, whether they were caught, literally, or less literally. Mine is an anthropological take on what has been mostly a sociological tradition. I develop this elsewhere (Varenne, forthcoming).

22 Garfinkel developed his ideas against Parsonian "theories of action." His critique would equally apply to all theorizing by Bourdieu or Foucault.

23 This is an expansion of Garfinkel argumentation in the first chapter to Studies in Ethnomethodology (1967).

24 An argument could probably be made that these experiments actually are experiments in anthropological (science) fiction; that is, they artificially produce a cultural arbitrary, enforced hegemonically, and thus let people perform what they must always perform, an improvisation that reveals their conditions, their puzzlement, and their temporary solutions. This what all cultural arbitraries require-that is, an enhanced practical awareness, not a suppression of this awareness.

25 See also Deshen (1992).

26 I developed this argument elsewhere (Varenne 1995). The importance of Durkheim's legacy, reinterpreted, is acknowledged by Garfinkel in the subtitle of his 2002 book, Working Out Durkheim's Aphorism. Ann Rawls has been developing these themes in her reconsideration of Durkheim's Elementary Forms of the Religious Life (2004). Richard Hilbert's (1992) introduction to ethnomethodology makes similar points.

27 It might be more indicative of this process to write that one has been "caught" in the line, in the same way that one may be caught in witchcraft (Favret-Saada 1977/1980) or in the routine of a halfway house for recovering drug addicts (Wieder 1974).

28 Geertz (1972/1973) put "deep play" into the anthropological vocabulary. In recent years, play has been taken as seriously as it had been by Bateson earlier (1955/1972). See Varenne and Cotter (2006) on play in delivery rooms; Mullooly and Varenne (2006) on play with authority in classrooms; and Ortner (1999) on Sherpa mountaineering as a "game." Boon (1999) has gone furthest in attempting to build a theory of culture on the ubiquitous extravagance of human beings as they deal with their worlds.

29 While Garfinkel is not generally known as a sociologist concerned with power and violence, it may actually be the case that he has given us better tools to understand how they are applied than Bourdieu, Foucault, or any other of the "critical" sociologists ever did. "Symbolic" violence, Bourdieu told us, must be an everyday practice. But only Garfinkel showed us how this would happen and its consequences, such as in his paper on status 
degradation (1956) and in his work on "passing," seen as an acknowledgment of power and a recognition that it is never total (1967, chap. 5).

\section{References}

Adely, Fida J. 2007. Is music haram? Jordanian girls educating each other about nation, faith and gender in school. Teachers College Record 109:1663-1681.

Anderson, J., M. Kendrick, T. Rogers, and S. Smythe, eds. 2005. Portraits of literacy across families, communities, and schools. Mahwah, NJ: Erlbaum.

Bartlett, Lesley. 2007. Human capital or human connections? The multiple meanings of education. Teachers College Record 109:1613-1636.

Bateson, Gregory. 1955/1972. A theory of play and fantasy. In Steps to an ecology of mind, 177-93. New York: Ballantine Books.

Bateson, Gregory. 1972. Steps to an ecology of mind. New York: Ballantine Books.

Boas, Franz. (1962). Anthropology and modern life. New York: Norton.

Bond, George. 1981. Social economic status and educational achievement. Anthropology and Education Quarterly 12:227-57.

Boon, James. 1999. Verging on extra-Vagance: Anthropology, history, religion, literature, arts . . . showbiz. Princeton, NJ: Princeton Univ. Press.

Bourdieu, Pierre. 1970/1977. Outline of a theory of practice. Trans R. Nice. Cambridge, UK: Cambridge Univ. Press.

Bourdieu, Pierre. 1979/1984. Distinction. Trans R. Nice. Cambridge, MA: Harvard Univ. Press.

Bourdieu, Pierre, and Jean-Claude Passeron. 1977/1970. Reproduction in education, society and culture. Trans R. Nice. Beverly Hills, CA: Sage.

Bourgois, Philippe. 1996. Confronting anthropology, education, and inner-city apartheid. American Anthropologist 101:249-58.

Calhoun, C., and F. Ianni., eds. 1976. The anthropological study of education. The Hague, The Netherlands: Mouton.

Carroll, Lewis. 1871. Through the looking-glass. New York: Barnes and Noble.

de Certeau, Michel. 1980/1984. The practice of everyday life. Berkeley: Univ. of California Press.

Cremin, Lawrence. 1970. American education: The colonial experience. History of American Education, vol. 1. New York: Harper \& Row.

Cremin, Lawrence. 1974. Further notes toward a theory of education. Notes on Education. New York: Institute of Philosophy and Politics of Education, Teachers College, Columbia Univ.

Cremin, Lawrence. 1975/2007. Public education and the education of the public. Teachers College Record 77:1-12. Repr. Teachers College Record 109:1545-1558.

Cremin, Lawrence. 1976. Public education. New York: Basic Books.

Cremin, Lawrence. 1978. The education of the educating professions. Research Bulletin 18. New York: Horace Mann-Lincoln Institute, Teachers College, Columbia Univ.

Cremin, Lawrence. 1980. American education: The national experience, 1783-1876. History of American Education, vol. 2. New York: Harper \& Row.

Cremin, Lawrence. 1988. American education: The metropolitan experience, 1876-1980. History of American Education, vol. 3. New York: Harper \& Row.

Deshen, Shlomo. 1992. Blind people: The private and public life of sightless Israelis. Albany: State Univ. of New York Press.

Dewey, John. 1916/1966. Democracy and education. New York: Free Press. 
Doerr, Neriko. (2004). Desired division, disavowed division: An analysis of the labeling of the bilingual unit as separatist in an Aotearoa/New Zealand school. Anthropology and Education Quarterly 35:233-53.

DuBois, Cora. 1955. Some notions on learning intercultural understanding. In Education and anthropology, ed. G. Spindler, 89-105. Stanford: Stanford Univ. Press.

Favret-Saada, Jeanne. 1977/1980. Deadly words: Witchcraft in the bocage. Trans. C. Cullen. New York: Cambridge Univ. Press.

Foucault, Michel. 1975/1978. Discipline and punish. New York: Penguin Books.

Garfinkel, Harold. 1956. Conditions of successful degradation ceremonies. American Journal of Sociology 61:420-24.

Garfinkel, Harold. 1967. Studies in ethnomethodology. Englewood Cliffs, NJ: Prentice-Hall.

Garfinkel, Harold. 2002. Ethnomethodology's program: Working out Durkheim's aphorism. Lanham, MD: Rowman \& Littlefield.

Geertz, Clifford. 1972/1973. Deep play: Notes on the Balinese cockfight. In The interpretation of cultures, 412-53. New York: Basic Books.

Gershon, Ilana 2007. Outspoken indigenes and nostalgic migrants: MÇori and Samoan educating performances in an Aotearoa New Zealand cultural festival. Teachers College Record 109:1797-1820.

Greenfield, P., and Jean Lave. 1982. Cognitive aspects of informal education. In Cultural perspectives on child development, ed. E. Wagner and P. Stevenson, 181-207. San Francisco: W. H. Freeman and Company.

Gregory, E., S. Long, and D. Volk, eds. 2004. Many pathways to literacy: Young children learning with siblings, grandparents, peers and communities. New York: Routledge Falmer.

Gundaker, Grey. 1998. Signs of diaspora, diaspora of signs: Literacies, creolization, and vernacular practice in African America. New York: Oxford Univ. Press.

Gundaker, Grey. 2007. Hidden education among African Americans during slavery. Teachers College Record 109:1591-1612.

Gundaker, Grey.Forthcoming. Give me a sign: African Americans, print, and practice, 1790-1840. In An extensive republic: Print, culture and society in the new nation, history of the book in America, ed. Robert Gross and Mary Kelley. New York: Cambridge Univ. Press.

Henry, Jules. 1963. Culture against man. New York: Random House.

Hewett, Edgar. 1904. Anthropology and education American Anthropologist 6: 574-75.

Hewett, Edgar. 1905. Ethnic factors in education. American Anthropologist 7:116.

Hilbert, Richard. 1991. Ethnomethodological recovery of Durkheim. Sociological Perspectives 34:337-57.

Hilbert, Richard. 1992. The classical roots of ethnomethodology. Chapel Hill: Univ. of North Carolina Press.

Illich, Ivan. 1970. Deschooling society. New York: Harper \& Row.

Jakobson, Roman. 1960. Concluding statement: Linguistics and poetics. In Style in language, ed. T. Sebeok, 350-77. New York: Wiley.

Johnson, Tracy P. 2007. Enclothing identity: A Hmong girl's journey into the politics of identification in Thailand. Teachers College Record 109:1637-1662.

Jordan, Brigitte. 1989. Cosmopolitical obstetrics: Some insights from the training of traditional midwives. Social Science and Medicine 28:925-44.

de Jouvenel, Bertrand. 1977/1963. The pure theory of politics New Haven, CT: Yale Univ. Press.

Kalmar, T. 2001. Illegal alphabets and adult literacy: Latino migrants crossing the linguistic border. Mahwah, NJ: Erlbaum.

Kimball, Solon. 1974. Culture and the educative process: An anthropological perspective. New York: Teachers College Press. 
Klemp, Nathaniel, Ray McDermott, Jason Raley, Matthew Thibeault, Kimberly Powell, and Daniel J. Levitin. Forthcoming. Plans, takes, mis-takes: Sequence and learning in jazz. Journal of the Learning Sciences.

Lareau, Annette 1989. Home advantage: Social class and parental intervention in elementary education. New York: Falmer Press.

Lave, Jean, and Ray McDermott. 2002. Estranged learning. Outlines 1:19-48.

Lave, Jean, and Etienne Wenger. 1991. Situated learning: Legitimate peripheral participation. New York: Cambridge Univ. Press.

Leichter, Hope. 1975. Families as educators. New York: Teachers College Press.

Leichter, Hope, ed. 1979. Families and communities as educators. New York: Teachers College Press.

Lévi-Strauss, Claude. 1962/1966. The savage mind. Chicago: Univ. of Chicago Press.

Levinson, Bradley. 1999. Resituating the place of educational discourse in anthropology. American Anthropologist 101:594-604.

Levinson, Bradley, ed. 2000. Schooling the symbolic animal. New York: Rowman and Littlefield.

Lewis, Oscar. 1966. The culture of poverty. Scientific American 5:19-25.

Lindquist, Harry. 1971. A world bibliography of anthropology and education, with annotations. In Anthropological perspectives on education, ed. M. Wax, S. Diamond, and F. Gearing, 307-84. New York: Basic Books.

Lorimer, Anne. 2003. Reality world: Constructing reality through Chicago's Museum of Science and Industry. PhD diss., Univ. of Chicago.

Lorimer, Anne. 2007. The cockpit's empty chair: Education through appropriating alienation at a technology museum. Teachers College Record 109:1707-1724.

Lynd, Robert, and Helen Lynd. 1929/1956. Middletown: A study in modern American culture. New York: Harcourt, Brace and World.

Mahiri, Jabari., ed. 2004. What they don't learn in school: Literacy in the lives of urban youth. New York: Peter Lang Publishing.

McDermott, R. P. 1993. The acquisition of a child by a learning disability. In Understanding practice, ed. S. Chaiklin and J. Lave, 269-305. New York: Cambridge Univ. Press.

McDermott, R. P. 2000. A century of Margaret Mead. Teachers College Record 103:843-67.

Mehan, H., A. Hertwerk, and J. Meihls. 1986. Handicapping the handicapped. Stanford, CA: Stanford Univ. Press.

Merleau-Ponty, Maurice. 1969/1973. The prose of the world. Trans. J. O'Neil . Evanston, IL: Northwestern Univ. Press.

Miller, D., ed. 1993. Unwrapping Christmas. Oxford: Clarendon Press.

Miller, D., ed. 2001a. Car cultures. New York: Berg.

Miller, D., ed. 2001b. Home possessions. New York: Berg.

Miller, D., ed. 2001c. The Internet. New York: Berg.

Moll, Luis, C., Cathy Amanti, and Norma Gonzalez, eds. (2005). Funds of knowledge: Theorizing practices in households and classrooms. Mahwah, NJ: Erlbaum.

Mullooly, James, and Hervé Varenne. 2006. Playing with pedagogical authority. In Classroom authority: Theory, research, and practice, ed. J. Pace and A. Hemmings, 63-86. Mahwah, NJ: Erlbaum.

Mullooly, J. 2007. Regrading the eighth grade: Disciplining those who discipline in a Jesuit middle school. Teachers College Record 109:1747-1774.

Naddeo, Merry. 1991. The New Life Singers: A discourse analysis of street kids doing a choir rehearsal. PhD diss., Teachers College, Columbia Univ.

Ortner, Sherry. 1999. Life and death on Mt. Everest. Princeton, NJ: Princeton Univ. Press.

Parsons, Talcott, and Edward Shils 1951. Towards a general theory of action. New York: Harper and Row. 
Pelissier, Catherine. 1991. The anthropology of teaching and learning. Annual Reviews of Anthropology 20:75-95.

Pollock, Mica. 2004. Colormute: Talk dilemmas in an American school. Princeton: Princeton Univ. Press.

Rancière, Jacques. 1983/2004. The philosopher and his poor. Trans J. Drury, C. Oster, and A. Parker. Durham, NC: Duke Univ. Press.

Rancière, Jacques. 1991/1999. The ignorant schoolmaster: Five lessons in intellectual emancipation. Trans. K. Ross. Stanford: Stanford Univ. Press.

Rawls, Anne. W. 2004. Epistemology and practice: Durkheim's "The elementary forms of the religious life." New York: Cambridge Univ. Press.

Sabin, Portia. 2004. Truths, universally acknowledged: Friendship and romance as education between college students in America. PhD diss., Columbia Univ.

Sabin, Portia. 2007. On sentimental education among college students. Teachers College Record 109:1682-1704.

Seyer-Ochi, Ingrid. 2002. Smart on the under, wise to the streets: Mapping the landscapes of urban youth. PhD diss., Stanford Univ.

Silverstein, Michael. 1993. Metapragmatic discourse and metapragmatic function. In Reflexive language: Reported speech and metapragmatics, ed. J. Lucy, 33-58. Cambridge: Cambridge Univ. Press.

Singleton, John. 1999. Reflecting on the reflections: Where did we come from? Where are we going? Anthropology and Education Quarterly 30:455-59.

Spindler, George, ed. 1955. Education and anthropology. Stanford, CA: Stanford Univ. Press.

Stratton, Alison. 2007. Hard of Hearing in Sweden: Educating about and for pathology. Teachers College Record 109:1775-1796.

Taylor, Denny, and Catherine Dorsey-Gaines. 1988. Growing up literate: Learning from innercity families. Portsmouth, NH: Heinemann.

Varenne, Hervé. 1995.The social facting of education: Dukheim's legacy. Journal of Curriculum Studies 27:373-89.

Varenne, Hervé. Forthcoming. The production of difference in interaction: On culturing conversation through play. In Theoretical approaches to dialogue analysis, ed. L. N. Berlin. Tübingen, Germany: Max Niemeyer Verlag.

Varenne, Hervé, and Mary Cotter. 2006. Dr. Mom? Conversational play and the submergence of professional status in childbirth. Human Studies 29:77-105.

Varenne, Hervé, and Ray McDermott. 1998. Successful failure. Boulder, CO: Westview.

Verrips, J., and B. Meyer. 2001. Kwaku's car: The struggles and stories of a Ghanaian longdistance taxi driver. In Car cultures, ed. D. Miller, 153-84. Oxford, UK: Berg.

Wieder, D. Lawrence 1974. Language and social reality: The case of telling the convict code. The Hague, The Netherlands: Mouton.

Wortham, Stanton. 2006. Learning identity: The joint emergence of social identification and academic learning. New York: Cambridge Univ. Press.

HERVE VARENNE is professor of education at Teachers College, Columbia University. As a cultural anthropologist, his major interests center on the processes that produce particular conditions for human beings in history, and their consequences. His most recent book, written with Ray McDermott, deals with the consequences of American schooling (Successful Failure, Westview 1998). Three recent articles develop the 
themes: with Ray McDermott, "Reconstructing Culture" (In New Horizons in the Ethnography of Education, ed. G. Spindler, Lawrence Erlbaum Associates, 2006); with Mary Cotter, "Dr. Mom? Constituting, and Playing with, Statuses during Hospital Labor" (Human Studies, 2006); and "On NCATE Standards and Culture at Work" (Anthropology and Education Quarterly, 2007). 